\title{
Presence and Absence of Bats Across Habitat Scales in the Upper Coastal Plain of South Carolina
}

\author{
W. MARK FORD, ${ }^{1}$ United States Department of Agriculture Forest Service, Northeastern Research Station, Parsons, W 26287, USA \\ JENNIFER M. MENZEL, United States Department of Agriculture Forest Service, Northeastern Research Station, Parsons, WV 26287, USA \\ MICHAEL A. MENZEL, Division of Forestry, West Virginia University, Morgantown, W 26505-6125, USA \\ JOHN W. EDWARDS, Division of Forestry, West Virginia University, Morgantown, WW 26505-6125, USA \\ JOHN C. KILGO, United States Department of Agriculture Forest Service, Southern Research Station, New Ellenton, SC 29809, USA
}

\begin{abstract}
During 2001, we used active acoustical sampling (Anabat II) to survey foraging habitat relationships of bats on the Savannah River Site (SRS) in the upper Coastal Plain of South Carolina. Using an a priori information-theoretic approach, we conducted logistic regression analysis to examine presence of individual bat species relative to a suite of microhabitat, stand, and landscape-level features such as forest structural metrics, forest type, proximity to riparian zones and Carolina bay wetlands, insect abundance, and weather. There was considerable empirical support to suggest that the majority of the activity of bats across most of the 6 species occurred at smaller, stand-level habitat scales that combine measures of habitat clutter (e.g., declining forest canopy cover and basal area), proximity to riparian zones, and insect abundance. Accordingly, we hypothesized that most foraging habitat relationships were more local than landscape across this relatively large area for generalist species of bats. The southeastern myotis (Myotis austroriparius) was the partial exception, as its presence was linked to proximity of Carolina bays (bestapproximating model) and bottomland hardwood communities (other models with empirical support). Efforts at SRS to promote open longleaf pine (Pinus palustris) and loblolly pine (P. taeda) savanna conditions and to actively restore degraded Carolina bay wetlands will be beneficial to bats. Accordingly, our results should provide managers better insight for crafting guidelines for bat habitat conservation that could be linked to widely accepted land management and environmental restoration practices for the region. (JOURNAL OF WILDLIFE MANAGEMENT 70(5):1200-1209; 2006)
\end{abstract}

\section{Key words}

acoustical sampling, bat foraging, Carolina bay, echolocation, habitat model, pine savanna.

In forested landscapes, distributional patterns of bats are influenced by a complex interplay of habitat factors from the individual tree and stand-level to the landscape level, as well as prey resources, temporal factors, climate, and the autoecology of individual species of bats. Common to all points on the landscape and across all habitat scales, presence of bats at a single location at any moment can depend upon time, temperature, humidity, precipitation, barometric pressure, wind speed, ambient light intensity, and abundance and availability of insects (Barclay 1985, Clem 1993, Hayes 1997, Broders et al. 2003). At smaller habitat scales (e.g., forest canopy gap to forest stand or patch), activity can be related to proximity of riparian habitat, forest structural characteristics, echolocation characteristics, wing morphology, and prey preference of bat species (Aldridge and Rautenbach 1987, Jung et al. 1999, Menzel et al. 2005b). At larger landscape scales, bat presence is often related to overall abundance of day roosts; proximity of foraging habitat to day-roost sites; quality, density, and spatial juxtaposition of all available foraging habitats; and frequency and cumulative nature of disturbances on the landscape (Best and Hudson 1996, Crampton and Barclay 1997, Evelyn et al. 2004).

Recent efforts that have attempted to elucidate these processes, and their single and synergistic ecological agents operating across spatial and temporal scales, have shown

${ }^{1}$ E-mail: mford@fs.fed.us strong linkages between activity of bats and a combination of microhabitat and landscape variables (Gehrt and Chelsvig 2003, 2004). Other research suggests that bat activity is a function of the features of smaller forest patch (Erickson and West 2003, Ford et al. 2005) or specialized landscape components (Grindal et al. 1999, Seidman and Zabel 2001, Johnson et al. 2003, Menzel et al. 2005b). Unlike day-roost data, the difficulty of collecting adequate activity data from radiotelemetry over numerous areas or among multispecies communities and the imprecise ability to link acoustical data with individual bats has impeded our understanding of bat activity patterns and habitat associations (Russ and Montgomery 2002, Broders 2003).

Within the Southern Pine Region (SPR) of the Coastal Plain of the southeastern United States, bat communities are considered to be of high conservation value (Menzel et al. 2003). This portion of North America is undergoing unprecedented landscape change caused by rapid growth of the human population and associated urban and exurban sprawl (Wear and Greis 2002). More importantly, this rapid pace of forest habitat alteration is projected to continue for the foreseeable future (Alig and Butler 2004). Forest conversion or alteration associated with urban sprawl is further complicated because composition of many extant forests is expected to continue shifting to more intensively managed plantation systems at least through the first 3 decades of the 21st Century (Wear and Greis 2002). However, with no threatened or endangered species such as 
the Indiana bat (Myotis sodalis) serving as regulatory drivers to encourage monitoring, collection of ecological data necessary for the management and conservation of dayroost resources, and foraging habitats for the region's bat assemblage has been relatively limited. To date, bat research in the SPR has been restricted to a small portion of South Carolina (Menzel et al. 2003, Carter et al. 2004, Menzel et al. 2005a,b), Mississippi (Elmore et al. 2005), and Georgia (Krishon et al. 1997, Menzel et al. 1998).

Understanding how current land use patterns and future land use changes will impact bat communities in the SPR requires development of species-specific, quantitative habitat models over all relevant spatial and temporal scales. Remarkably insightful assessments of bat distribution patterns across a range of habitat scales (Johnson 2003, Ford et al. 2005) without requiring the restrictive assumptions required for measures of abundance (Hayes 2000) have been provided by sampling with Anabat zero-crossing period meter acoustical equipment used in a short-duration "active-search mode" to collect species-specific presenceabsence data in the central and southern Appalachian Mountains. We examined acoustically collected presenceabsence data on bats at 430 sample locations over a $780 \mathrm{~km}^{2}$ area in the SPR to relate bat presence or absence to various environmental parameters at the SRS, South Carolina, using an information-theoretic modeling approach. Based on previous research at Savannah River Site (SRS; Menzel et al. 2003, 2005a,b), we predicted that the presence of all or most bat species on site would be related to proximity or abundance of riparian and wetland habitats at both the stand and landscape-level scales, rather than to composition and heterogeneity of terrestrial landscapes consistent with foraging habitat niches at SRS described by Menzel et al. (2003). Conversely, we predicted that in an arthropod-rich, subtropical/warm-temperate forest setting, links between presence of bats and insect abundance and weather during the summer growing season would be weak or equivocal.

\section{Study Area}

We conducted our study on the 80,267-ha SRS, a United States Department of Energy nuclear weapons production and maintenance facility and National Environmental Research Park located in Aiken, Allendale, and Barnwell counties, in the upper Coastal Plain physiographic province of west-central South Carolina $\left(33^{\circ} 0^{\prime} 25^{\prime \prime} \mathrm{N}, 81^{\circ} 25^{\prime} 50^{\prime \prime} \mathrm{W}\right)$. The SRS had a humid subtropical/warm-temperate climate with an average summer and winter temperature of $27^{\circ} \mathrm{C}$ and $9^{\circ} \mathrm{C}$, respectively, and average annual rainfall of $120 \mathrm{~cm}$ (Workman and McLeod 1990).

Upland pine forests consisted largely of loblolly pine (Pinus taeda), longleaf pine (P. palustris), or slash pine ( $P$. elliotii) plantations that ranged from newly planted to older sawtimber-sized stands $(>60 \mathrm{yr})$ dominated the SRS $(62 \%)$. Following harvest, many stands of loblolly and slash pine were converted to longleaf pine, and many current midaged loblolly and longleaf pine stands are thinned and maintained as savannas to restore overstory conditions to promote and enhance conditions for the endangered redcockaded woodpeckers (Picolides borealis) and other plant and animals dependent upon that presettlement condition (Barton et al. 2005). Other forest types at the SRS included southern bottomland hardwoods and bald cypress (Taxodium distichum)-water tupelo (Nyssa aquatica) swamps $(14.8 \%)$, upland hardwoods $(3.4 \%)$, and mixed pinehardwood communities (5.2\%; Menzel et al. 2003, Imm and McLeod 2005). Aquatic habitats such as man-made reservoirs and ponds, Carolina bays, both forested and emergent, blackwater streams, and large river habitats were also common on the site (Workman and McLeod 1990). Scattered throughout the SRS, there were also permanent grassy or brushy conditions that consisted of roads, railroads, utility rights-of-way, and open areas around production facilities.

\section{Methods}

We used Anabat II detectors (Titley Electronics, Ltd., Ballina, New South Wales, Australia) linked to laptop computers using Anabat 6.3e software to determine presence of foraging bats at 430 survey locations on the SRS from late May through July 2001. Our survey points were located throughout the SRS. Approximately half ( $n=$ 217) of the points were centered at Forest Inventory and Analysis (FIA) plots, which were systematically located across the SRS on a $1,000-$ by $1,000-\mathrm{m}$ grid. To proportionally incorporate most of the habitats available on the area, we supplemented these FIA locations with 213 additional points both selectively (i.e., bridge crossings, Carolina bays, and lakes throughout) and randomly placed in community types under-represented in the FIA database (e.g., the bottomland hardwood stands along the Savannah River and the lower stream reaches on the SRS). In their entirety, bat survey points represented almost the complete range and variability of habitat conditions present at SRS. At each survey point, we actively monitored for bat presence for 20-minute periods by slowly sweeping the Anabat detector back and forth to scan for activity (Johnson et al. 2002, Ford et al. 2005). Sampling occurred from shortly after dusk to about $0100-0200$ hours in the early morning. We avoided sampling during evenings with low activity caused by high winds or moderate to heavy precipitation (Ford et al. 2005). We filtered recorded echolocation passes (Miller 2001) prior to analysis (Britzke and Murray 2000) and then identified species using Analook 4.7j and Analyze 2.0 software. To identify bats to species, we relied on a combination of qualitative and quantitative factors such as minimum and mean call note frequency, call note curvature, and call note slope developed from an echolocation call library representing all the species that could occur at the SRS (Menzel 1998, Menzel et al. 2005a). We were not able to discriminate between echolocation passes of the eastern red bat (Lasiurus borealis) and the Seminole bat ( $L$. seminolus), so we grouped these species in our acoustical identifications and subsequent analysis.

For all points, we accessed the Field Sampled Vegetation 
(FSVeg) database within the Natural Resources Information System framework with corresponding data on stand structure and vegetation type (USDA Forest Service 2005). From FSVeg classifications in the surrounding management compartment for each point, we broadly scored the vegetation type as pine (0) at 285 survey points or hardwood (1) at 145 survey points; the landscape setting as upland (0) at 337 survey points or bottomland (1) at 93 survey points; and the condition as open (0) at 88 survey points or forested (1) at 342 points. In addition to FSVeggenerated data, we also collected other data at each survey point to better relate bat species presence to habitat conditions. In daylight hours prior or after acoustical sampling, we assessed forest basal area $\left(\mathrm{m}^{2} / \mathrm{ha}\right)$ using a 10 factor prism and canopy cover using a sighting tube at 10 random locations within the 0.05 -ha circular plot around each survey site (Cook et al. 1995). Concurrent with acoustical sampling at a survey point, we conducted 10minute sweepnet passes for a very generalized, partial assessment of insect prey abundance (Hollifield and Dimmick 1995). We recorded temperature, wind speed, percentage of relative humidity, and barometric pressure using a handheld weather meter (Nielsen-Kellerman Inc., Boothwyn, Pennsylvania), and we made visual estimates of cloud cover and moon phase (percentage of disk illumination) during the acoustical sampling.

We used Geographic Information System coverages incorporating FSVeg measures and other SRS features in ArcView 3.2 (ERSI Inc., Redlands, California) to calculate simple linear distance from each acoustical survey point to the nearest water (streams, sloughs, rivers, ponds, or reservoirs), the nearest Carolina bay, and the nearest anthropogenically created permanent hard edge (e.g., roads, utility lines and rights-of-way, industrial complexes, landfills, and open remediation/reclamation sites). To assess overall landscape heterogeneity around each survey point, we enumerated the number of distinct FSVeg-defined habitats based on either dissimilar vegetation classification or disparate forest stand age or stand condition within a 1$\mathrm{km}$ radius of the survey points.

To examine the relation of each species of bat with the various microhabitat and stand- or landscape-level variables, we also developed a series of a priori logistic regression models (Hosmer and Lemeshow 2000, Russell et al. 2004, Wagner and Drickamer 2004). Based on our prior knowledge of bat foraging ecology at SRS (Menzel et al. 2002, Carter et al. 2004, Menzel et al. 2005a,b), the models we constructed were as follows: STRUCTURE, survey point basal area and overstory canopy cover; WATER, distance to nearest water feature; INSECT, total number of arthropods of all orders identified except arachnids from sweep-netting; 3-WAY, STRUCTURE + WATER + INSECT; BAY, distance to nearest Carolina bay; WEATHER, temperature, wind speed, barometric pressure, humidity, cloud cover, and moon illumination; LANDSCAPE, vegetation, landscape setting, condition, distance to anthropogenic edge, and landscape heterogeneity or number of distinct stands or compartments; and GLOBAL, all parameters. We tested for pairwise correlation among continuous variables using Spearman's rank correlation prior to fitting our a priori models with none used in our constructed models being highly autocorrelated $\left(r_{\mathrm{s}}>0.50\right)$. We evaluated models based on Akaike's Information Criterion corrected for small sample size $\left(\mathrm{AIC}_{c}\right), \mathrm{AIC}_{c}$ differences $\left(\triangle \mathrm{AIC}_{c}\right)$, and Akaike weights $\left(\omega_{i}\right)$. Although competing models that were within 7 units of $\mathrm{AIC}_{\min }$ had some empirical support for each species of bat, we drew our primary inference only from those competing models that were $<4$ units from $\mathrm{AIC}_{\text {min }}$ (Burnham and Anderson 1998). Additionally, for the bestapproximating model for each bat species, we calculated Hosmer and Lemeshow's goodness-of-fit and Nagelkerke's rescaled $R^{2}$ (SAS Institute 1995) to assess a relative measure of fit and strength of the models. We also used a jackknife procedure to compute a percentage for correct classification for correctly assigned presence (sensitivity) and absence (specificity) for those best models at a cutoff value of 0.50 (SAS Institute 1995).

To further aid in model interpretation and to better understand individual habitat variable effects on the presence and absence of bat species at SRS, we also compared each continuous or categorical/ordinal variable for each survey point by individual bat species' presence or absence using univariate Wilcoxon rank-sum tests or Fisher's Exact tests, respectively (Steel and Torrie 1980, SAS Institute 1990). For some variables compared using Wilcoxon rank-sum tests where we had reasonably strong knowledge of single direction outcomes common to all bat species (e.g., distance to water), we used 1-tailed tests. For all other variables compared using Wilcoxon rank-sum tests or all variables examined with Fisher's Exact test where variables likely varied across species or where we had no strong a priori expectation outcome (e.g., basal area, number of stands within 1-km of a survey point) we used 2-tailed tests.

\section{Results}

During 2001, we recorded 3,251 echolocation passes at 430 survey points at SRS: $1,491 \mathrm{red} / \mathrm{Seminole}$ passes at 216 sites; 474 eastern pipistrelle (Pipistrellus subflavus) passes at 72 sites; 359 evening bats (Nycticeius bumeralis) passes at 107 sites; 156 big brown bat (Eptesicus fuscus) passes at 53 sites; 155 Southeastern myotis (Myotis austroriparius) passes at 45 sites; and 110 hoary bat (Lasiurus cinereus) passes at 21 sites. We were not able to identify the remaining 506 passes due to poor call quality or insufficient call duration. Although the Brazilian free-tailed bat (Tadarida brasiliensis) has been infrequently documented at SRS (Menzel et al. 2002), we did not record any. Rafinesque's big-eared bat (Corynorbinus rafinesquii) also was present at the SRS in low numbers (Menzel et al. 2002, 2003); however, its low echolocation intensity renders it acoustically undetectable (Menzel et al. 2005b).

The BAY model was the best-approximating model for southeastern myotis with LANDSCAPE and WATER also 
Table 1. Supported logistic regression models within 7 units $A I C_{\text {min }}$ explaining the influence of habitat variables on the presence of 6 bat species/groups at 430 acoustical survey sites on the Savannah River Site, South Carolina, USA, 2001. Model rankings were based on Akaike's Information Criterion corrected for small sample size $\left(\mathrm{AlC}_{c}\right){ }^{\mathrm{a}}$

\begin{tabular}{|c|c|c|c|c|}
\hline Model & $\mathrm{K}$ & $\mathrm{AlC}_{\mathrm{c}}$ & $\mathrm{AAIC}_{\mathrm{c}}$ & $\omega_{i}$ \\
\hline \multicolumn{5}{|c|}{ Southeastern myotis } \\
\hline $\mathrm{BAY}$ & 2 & 280.57 & 0.00 & 0.66 \\
\hline LANDSCAPE & 6 & 282.97 & 2.40 & 0.20 \\
\hline WATER & 2 & 284.03 & 3.46 & 0.12 \\
\hline \multicolumn{5}{|l|}{ Eastern pipistrelle } \\
\hline 3-WAY & 5 & 370.50 & 0.00 & 0.76 \\
\hline WATER & 2 & 372.94 & 2.44 & 0.22 \\
\hline \multicolumn{5}{|l|}{ Big brown bat } \\
\hline STRUGTURE & 3 & 315.44 & 0.00 & 0.56 \\
\hline 3-WAY & 5 & 316.59 & 1.15 & 0.32 \\
\hline WATER & 2 & 318.67 & 3.23 & 0.11 \\
\hline \multicolumn{5}{|c|}{ Red / Seminole bat } \\
\hline 3-WAY & 5 & 550.66 & 0.00 & 0.99 \\
\hline \multicolumn{5}{|l|}{ Hoary bat } \\
\hline GLOBAL & 16 & 151.25 & 0.00 & 0.79 \\
\hline WATER & 2 & 154.80 & 3.55 & 0.13 \\
\hline 3-WAY & 5 & 156.08 & 4.83 & 0.07 \\
\hline \multicolumn{5}{|l|}{ Evening bat } \\
\hline STRUCTURE & 3 & 423.13 & 0.00 & 0.88 \\
\hline 3.WAY & 5 & 427.19 & 4.06 & 0.12 \\
\hline
\end{tabular}

${ }^{a}$ See text for individual model composition. $\mathrm{K}=$ the number of estimable parameters in approximating model. $\Delta \mathrm{AIC}_{c}=$ the difference in value between $\mathrm{AlC}_{C}$ of the current model versus the bestapproximating model $\left(\mathrm{AlC}_{\mathrm{min}}\right)$ for each bat species/group. $\omega_{i}=$ Akaike weight; the probability that the current model $(i)$ is the best approximating among those considered for each bat species/group.

receiving support (Table 1). Distance to Carolina bays was a significant model component (Table 2). For southeastern myotis, distances to water, distances to Carolina bays, and insect abundances were less where the species was present versus where it was not recorded, whereas the opposite was true for distances to anthropogenic corridors (Table 3). Southeastern myotis proportionally were more likely to be present in hardwood (23 of 145 sites) rather than pine communities ( 22 of 285 sites; Fisher's exact test $P=0.012$ ) and in bottomland (19 of 93 sites) rather than upland habitats (26 of 337 sites; Fisher's exact test $P=0.001$ ).

The 3-WAY model was the best approximating for explaining presence of eastern pipistrelles, with WATER also receiving support (Table 1). Distance to water and canopy cover were significant model components (Table 2). For eastern pipistrelles, insect abundance was greater; distances to water, distances to Carolina bay, canopy cover, and basal area were less where the species was present versus where it was not recorded (Table 3). Eastern pipistrelles proportionally were more likely to be present in habitats considered open (21 of 88 sites) than in closed or forested habitats (51 of 342 sites; Fisher's exact test, $P=0.054$ ).

The STRUCTURE model was the best-approximating model for the big brown bat with 3-WAY and WATER also receiving support (Table 1). Basal area was a significant component of the best-approximating model for big brown bats (Table 2). For big brown bats, distances to water, canopy cover, and basal area were less where the species was present versus where it was not recorded (Table 3). Big brown bats were more likely to be present in habitats considered open (16 of 88 sites) than in closed or forested habitats ( 37 of 342 sites; Fisher's exact test, $P=0.069$ ).

The 3-WAY model was the best-approximating for the $\mathrm{red} /$ Seminole bat group (Table 1). Canopy cover and basal area were significant components of the best-approximating model (Table 2). For red/Seminole bats, insect abundance and distances to anthropogenic corridor were greater, and canopy cover and basal area were less where this combined group was present versus where it was not recorded (Table $3)$. Red/Seminole bats were more likely to be present in hardwood (88 of 145) rather than pine communities (128 of 285; Fisher's exact test, $P=0.002)$ and in open habitats (54 of 88 sites) rather than in closed or forested habitats (162 of 342 sites; Fisher's exact test $P=0.023$ ).

The GLOBAL model was the best approximating for hoary bats, with WATER and 3-WAY also receiving support (Table 1). Distance to water, insect abundance, distance to anthropogenic corridors, and number of stands/ habitats within $1 \mathrm{~km}$ all were significant components of the GLOBAL model (Table 2). For hoary bats, the number of stands/habitats within $1 \mathrm{~km}$ and canopy cover were less where the species was present versus where it was not recorded (Table 3). Hoary bat presence and absence was equitably distributed among all landscape conditions (Fisher's exact test $P>0.1$ ).

The STRUCTURE model was the best-approximating model for the evening bat with the 3-WAY model also receiving support (Table 1). Canopy cover and basal area were significant components of the best-approximating model (Table 2). For evening bats, insect abundances were greater; distances to water, canopy cover, and basal area were less where the species was present than where it was not recorded (Table 3). Evening bats were more likely to be present in hardwood (51 of 145 sites) rather than in pine communities ( 56 of 285 sites; Fisher's exact test, $P=0.001$ ) and in open habitats ( 30 of 88 sites) than in closed or forest habitats (77 of 342 sites; Fisher's exact test, $P=0.027$ ).

\section{Discussion}

The logistic regression models and univariate comparisons were consistent with our expectations for presence-absence data for bats at SRS. Presence of bats generally was linked more to microhabitat or stand-level structural conditions and the landscape-level variable of proximity to riparian habitat. This was demonstrated by the difference in canopy cover, basal area, distance to water in univariate comparisons, and the support for the STRUCTURE and 3-WAY models for big brown bats, evening bats, eastern pipistrelles, and the red/Seminole bat group. Proximity to riparian habitats was not the most supported or parsimonious model as might have been suggested by the overwhelming abundance of echolocation passes recorded at riparian versus upland sites at SRS (Menzel et al. 2005b); either the 
Table 2. Best approximating logistic regression models explaining presence of 6 bat species/groups at 430 acoustical survey sites on the Savannah River Site, South Carolina, USA, 2001.

\begin{tabular}{|c|c|c|c|c|c|}
\hline Parameter & Estimate & SE & $\boldsymbol{P}>\chi_{\text {Wald }}^{2}$ & Odds ratio & $95 \% \mathrm{CL}$ \\
\hline $\begin{array}{l}\text { Southeastem myotis (B } \\
\text { Intercept } \\
\text { Distance to bay }\end{array}$ & $\begin{array}{r}-1.67 \\
-0.001\end{array}$ & $\begin{array}{l}0.21 \\
0.0002\end{array}$ & $\begin{array}{c}<0.0001 \\
0.007\end{array}$ & 1.00 & $0.99-1.00$ \\
\hline $\begin{array}{l}\text { Eastern pipistrelle ( } 3-W \\
\text { Intercept } \\
\text { Basal area } \\
\text { Canopy cover } \\
\text { Distance to water } \\
\text { Insect abundance }\end{array}$ & $\begin{array}{c}-0.79 \\
-0.02 \\
-1.02 \\
-0.004 \\
-0.002\end{array}$ & $\begin{array}{l}0.22 \\
0.05 \\
0.60 \\
0.002 \\
0.01\end{array}$ & $\begin{array}{l}0.0004 \\
0.713 \\
0.089 \\
0.003 \\
0.829\end{array}$ & $\begin{array}{l}0.98 \\
0.36 \\
0.99 \\
0.99\end{array}$ & $\begin{array}{l}0.90-1.07 \\
0.11-1.17 \\
0.99-1.00 \\
0.98-1.01\end{array}$ \\
\hline $\begin{array}{l}\text { Big brown bat (STRUC } \\
\text { Intercept } \\
\text { Basal area } \\
\text { Canopy cover }\end{array}$ & $\begin{array}{r}-1.48 \\
-0.10 \\
-0.33\end{array}$ & $\begin{array}{l}0.20 \\
0.06 \\
0.67\end{array}$ & $\begin{array}{c}<0.0001 \\
0.088 \\
0.622\end{array}$ & $\begin{array}{l}0.91 \\
0.72\end{array}$ & $\begin{array}{l}0.82-1.01 \\
0.20-2.65\end{array}$ \\
\hline $\begin{array}{l}\text { Hoary bat (GLOBAL) } \\
\text { Intercept } \\
\text { Vegetation } \\
\text { Setting } \\
\text { Condition } \\
\text { Habitat number } \\
\text { Distance to corridor } \\
\text { Distance to water } \\
\text { Distance to bay } \\
\text { Humidity } \\
\text { Barometric pressure } \\
\text { Moon } \\
\text { Windspeed } \\
\text { Cloud cover } \\
\text { lnsect abundance } \\
\text { Basal area } \\
\text { Canopy cover }\end{array}$ & $\begin{array}{c}27.89 \\
-0.07 \\
-0.36 \\
0.65 \\
-0.33 \\
-0.01 \\
-0.02 \\
-0.002 \\
0.03 \\
-0.03 \\
-1.35 \\
0.73 \\
-0.03 \\
0.03 \\
0.10 \\
-1.76\end{array}$ & $\begin{array}{c}57.10 \\
0.71 \\
0.83 \\
0.82 \\
0.13 \\
0.01 \\
0.01 \\
0.0003 \\
0.02 \\
0.06 \\
4.89 \\
0.49 \\
0.01 \\
0.20 \\
0.09 \\
1.32\end{array}$ & $\begin{array}{l}0.625 \\
0.919 \\
0.660 \\
0.426 \\
0.007 \\
0.071 \\
0.011 \\
0.387 \\
0.254 \\
0.614 \\
0.782 \\
0.135 \\
0.019 \\
0.010 \\
0.281 \\
0.180\end{array}$ & $\begin{array}{l}0.93 \\
0.70 \\
1.98 \\
0.72 \\
0.99 \\
0.98 \\
1.00 \\
1.07 \\
1.09 \\
0.26 \\
2.09 \\
0.97 \\
1.03 \\
1.10 \\
0.17\end{array}$ & $\begin{array}{c}0.23-3.74 \\
0.14-3.51 \\
0.39-9.52 \\
0.56-0.91 \\
0.98-1.00 \\
0.97-1.00 \\
0.99-1.00 \\
0.98-1.07 \\
0.87-1.09 \\
0.001-999.99 \\
0.79-5.74 \\
0.95-1.00 \\
1.01-1.05 \\
0.92-1.32 \\
0.01-2.26\end{array}$ \\
\hline
\end{tabular}

${ }^{\text {a }}$ Rescaled $R^{2}=0.05$, goodness-of-fit $P=0.145$, correct classification (specificity) $=89 \%$.

${ }^{b}$ Rescaled $R^{2}=0.11$, goodness-of-fit $P=0.719$, correct classification (specificity) $=83 \%$.

${ }^{c}$ Rescaled $R^{2}=0.05$, goodness-of-fit $P=0.292$, correct classification (specificity) $=88 \%$.

d Rescaled $R^{2}=0.16$, goodness-of-fit $P=0.306$, correct classification $=65 \%$.

${ }^{\text {e }}$ Rescaled $R^{2}=0.34$, goodness-of-fit $P=0.992$, correct classification $=95 \%$.

${ }^{f}$ Rescaled $R^{2}=0.21$, goodness-of-fit $P=0.135$, correct classification (specificity) $=75 \%$.

WATER or 3-WAY models (that contained distance to water) had empirical support among our AIC measures for most species/group. Our modeling effort using presence and absence data largely was congruent with results generated from telemetry-derived habitat associations and acoustical studies that incorporated the relative abundance of echolocation passes among distinct habitat groupings in the southern United States (Owen et al. 2004, Ford et al. 2005, Menzel et al. 2005a,b). Similar to these past studies, the bat distribution patterns we detected in pine stands, hardwood stands, and open habitats within the forested matrix were positively related to proximity to water or to the presence of canopy gaps.

In contrast to microhabitat and stand-level features such as canopy gaps or riparian habitats, research efforts often have been frustrated by an inability to link the distribution of bats with landscape-level features in extensively forested environments (Hutchinson and Lacki 1999, Erickson and West 2003, Elmore et al. 2005, Loeb and O'Keefe 2006). Conversely, in highly fragmented landscapes where forests of any type are restricted to a small, patchy composition (e.g., in highly urbanized, agricultural, or grassland systems) forest patches themselves become a critical feature for many 
Table 3. Continuous habitat variables that differed $(P<0.1)$ between the presence or absence of 6 individual bat species/groups at 430 acoustical survey sites on the Savannah River Site, South Carolina, USA, 2001.

\begin{tabular}{|c|c|c|c|c|c|c|c|}
\hline Variable & \multicolumn{3}{|c|}{ Present } & \multicolumn{3}{|c|}{ Absent } & P \\
\hline \multicolumn{8}{|l|}{ Southeastern myotis } \\
\hline Distance lo bay (m) & 488.38 & 92.74 & 45 & 1059.96 & 68.87 & 385 & $0.001^{b}$ \\
\hline Distance to corridor (m) & 104.04 & 20.25 & 45 & 60.03 & 5.01 & 385 & $0.082^{b}$ \\
\hline Insect abundance & 8.71 & 1.13 & 45 & 9.25 & 0.79 & 385 & $0.031^{\mathrm{a}}$ \\
\hline \multicolumn{8}{|l|}{ Eastern pipistrelle. } \\
\hline Distance to water & 53.18 & 11.65 & 72 & 126.06 & 8.41 & 358 & $0.0001^{\mathrm{a}}$ \\
\hline Distance to bay & 681.35 & 111.68 & 72 & 1064.26 & 72.91 & 358 & $0.049^{b}$ \\
\hline Insect abundance & 10.81 & 1.90 & 72 & 8.87 & 0.77 & 358 & $0.085^{\mathrm{a}}$ \\
\hline Canopy cover $(\%)$ & 27.08 & 3.43 & 72 & 44.53 & 1.90 & 358 & $0.0002^{a}$ \\
\hline Basal area $\left(m^{2} / h a\right)$ & 7.07 & 1.14 & 72 & 11.97 & 0.62 & 358 & $0.001^{b}$ \\
\hline \multicolumn{8}{|l|}{ Big brown bat } \\
\hline Distance to corridor & 69.94 & 8.42 & 216 & 60.29 & 5.36 & 214 & $0.056^{\mathrm{b}}$ \\
\hline Insect abundance & 11.27 & 1.24 & 216 & 7.10 & 0.68 & 214 & $0.001^{a}$ \\
\hline Canopy cover & 32.17 & 2.26 & 216 & 51.29 & 2.41 & 214 & $0.0001^{b}$ \\
\hline Basal area & 7.73 & 0.66 & 216 & 14.60 & 0.83 & 214 & $0.0001^{\mathrm{b}}$ \\
\hline \multicolumn{8}{|l|}{ Hoany bat } \\
\hline No. stands/habitats & 4.19 & 0.43 & 21 & 4.94 & 0.07 & 409 & $0.055^{b}$ \\
\hline Canopy cover & 26.19 & 6.95 & 21 & 42.40 & 1.17 & 409 & $0.057^{\circ}$ \\
\hline \multicolumn{8}{|l|}{ Evening bat } \\
\hline Distance to water & 86.75 & 12.65 & 107 & 122.83 & 8.81 & 323 & $0.001^{a}$ \\
\hline Insect abundance & 11.74 & 1.95 & 107 & 8.36 & 0.70 & 323 & $0.071^{a}$ \\
\hline Ganopy cover & 20.56 & 2.73 & 107 & 48.58 & 1.95 & 323 & $0.0001^{\mathrm{b}}$ \\
\hline
\end{tabular}

Wilcoxon rank-sum test (1-tailed probability $>Z$ ).

${ }^{b}$ Wilcoxon rank-sum test (2-tailed probability $\left.>Z\right)$.

bats and therefore are routinely related to bat presence (Verboom and Huitema 1997, Gehrt and Chelsvig 2003, 2004, Murray and Kurta 2004, Lumsden and Bennett 2005). Presumably a threshold in degree of fragmentation exists in such landscapes, below which the simple presence of forest cover becomes more important than other aspects of patch quality (Avila-Flores and Fenton 2005). Where that threshold exists on SPR landscapes and/or where influences of stand age and type become more important in modifying or influencing habitat patterns of foraging bats are not known. A similar modeling effort in SPR landscapes that are rapidly urbanizing or in areas where agricultural and short-rotation pine plantation components are greater might show stronger links to landscape-level variables, as well as to forest patch-level characteristics, as older forested areas become more isolated and rare on the landscape (Wickramasinghe et al. 2003, Evelyn et al. 2004, Gehrt and Chelsvig 2004, Nielsen et al. 2005). Nonetheless, we believe the SRS probably provides better habitat for most bat species relative to the surrounding portions of the SPR dominated by agriculture, short-rotation forest management, and expanding urbanization (White 2005) because of its largely forested nature, with large expanses of mature pine forest with open canopies and savanna-like conditions and unbroken bottomland hardwoods.

At the individual species level, our work provides insight into how ongoing land management activities at the SRS may affect foraging activity of bats. For example, despite being characterized as a clutter-adapted species in terms of its foraging ecology (Menzel et al. 2003, 2005b), the evening bat showed positive responses to less cluttered and more open forest canopy structures, such as those found in maturing pine savanna habitats and older bottomland hardwood forests approaching gap-phase regeneration stages. Presence of evening bats was more likely in the relatively open than the cluttered habitats we monitored because prey densities possibly were greater. Although cluttered forested environments commonly contain higher densities of insects than do more open, upland habitats (Kalcounis and Brigham 1995, Hanula et al. 2000), many upland pine forests do not exhibit this same pattern (Tibbels and Kurta 2003, Menzel et al. 2005b). Alternatively, presence of evening bats might have been more probable in open rather than cluttered habitats because reduced clutter can result in relatively greater availability of insects, irrespective of overall prey abundance if the ease of 


\section{Nycticeius humeralis}

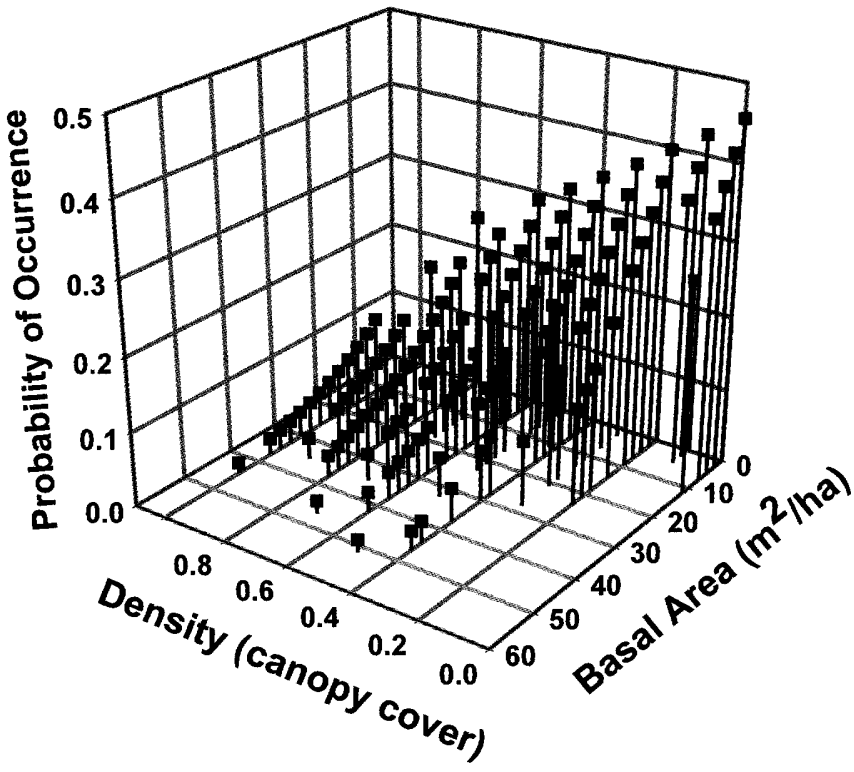

Figure 1. Predicted probability of occurrence of the evening bat at the Savannah River Site, South Carolina, USA, 2001 in relation to forest overstory canopy cover and basal area.

movement and foraging overcomes benefits derived from greater abundance of prey (Grindal and Brigham 1998).

Perhaps it is not surprising that a clutter-adapted species would respond favorably to some reductions in forest stem density or the creation of forest canopy gaps (Brigham et al. 1997) as has been demonstrated for the evening bat (Clem 1993, Menzel et al. 2002, 2005b). In addition to increased foraging opportunities or the ease thereof, the day-roost ecology of the evening bat previously has been linked to the type of roost conditions found in more open pine savanna habitats at the SRS (Menzel et al. 2001a). Our plotted predicted probabilities of occurrence from the best-approximating STRUCTURE model would similarly indicate that management efforts to increase and enhance this habitat condition (Barton et al. 2005) could have a positive impact on evening bats. Basal area and forest canopy conditions indicative of pine savanna habitats have the highest predicted likelihood of providing foraging habitat for evening bats at the SRS (Fig. 1). Accordingly, ongoing efforts at SRS to manage pine forests in savanna conditions to benefit other wildlife species such as the red-cockaded woodpecker also may benefit bat species such as the evening bat.

Our study indicates that the southeastern myotis is positively associated with proximity to Carolina bay in addition to links to bottomland hardwood and swamp forests in the SPR region as day-roost and foraging habitat as previously demonstrated (Clark et al. 1998, Menzel et al. 2003). On the SRS as well as the larger SPR region, most Carolina bays have been substantially altered or destroyed to support agriculture or short-rotation pine management (Kirkman et al. 1996, Menzel et al. 2005a). However, similar to pine savanna restoration activities, Carolina bays also are a focus of ongoing ecological restoration on SRS (Barton et al. 2005). Supporting our findings, Menzel et al. (2005a) observed that the relative abundance of southeastern myotis echolocation passes was greater at Carolina bays than in surrounding forests and that activity of southeastern myotis increased over Carolina bays that had recently had their hydrologic regimes restored by obstructing drainage ditches.

In our modeling, we did find it surprising that the presence of southeastern myotis was not more responsive to proximity to other riparian habitats or that there was no significant correlate with our broad landscape categorical variable of bottomland or riparian versus upland settings. We suspect that the location of the SRS in the upper Coastal Plain probably provides a considerable degree of habitat heterogeneity in terms of the interface between upland habitats, small riparian zones, and large river swamps than might occur closer to the coast in the lower Coastal Plain or in regions dominated by large river swamps and limited uplands, such as the lower Mississippi Alluvial Valley. Despite a wide distribution at the SRS, the majority of the Carolina bays do occur predominately in the upland settings adjacent to major bottomland areas. Accordingly, there probably was a degree of unknown spatial autocorrelation in our analyses that limited our ability to more clearly discriminate among these patterns relative to the southeastern myotis.

Despite showing some reasonable agreement or complementary information with preexisting or current research on bats at the SRS, we urge caution in extending these data beyond the general descriptions of bat-foraging habitat associations, as our study contained several limitations. Whereas our best-approximating models and other supported models define the "fundamental niches" (Zaniewski et al. 2002) of bats we studied, our models were relatively weak for the amount of variation explained in the presence and absence of each of the 6 bat species or the red batSeminole bat grouping. Our models indicate that the foraging habitat relationships across habitat scales at SRS are considerably more complicated than can be described by the microhabitat to landscape-level variables we assembled for analysis. Our strongest overall model for any species was the GLOBAL model for the hoary bat, indicating support for individual parameters or combinations thereof we did not consider, as well as unknown or unmeasured factors (Burnham and Anderson 1998, Russell et al. 2004), for which this kind of analysis has been appropriately criticized (Guthery et al. 2005).

Incomplete detection or inherent rarity introduces considerable bias in the use of logistic regression modeling to understand distribution and habitat association patterns (Odom et al. 2001, Royle et al. 2005). The hoary bat's uncommon occurrence at the SRS in the summer (Menzel et al. 2003) and its proclivity to forage above the forest canopy (Menzel et al. 2005b) contributed to our low detection of the species with a resulting low-quality model. 
Still, all variables associated significantly with the presence of hoary bat presence are those that have support in previous observations of the species (Hart et al. 1993, Owen et al. 2004).

Secondly, we sampled each survey point only once. Bat activity is notoriously variable from night to night within a season depending upon a host of factors such as weather conditions and prey availability (Warren et al. 2000), particularly in relation to temperature in high elevation habitats (Francl et al 2004) or in more northern latitudes (Vaughan et al. 1997, Wickramasinghe et al. 2003, but see also Tibbels and Kurta 2003). However, in an effort to standardize our sampling effort, we did not sample on nights with precipitation or high wind, when activity of bats would have been minimal. Also, during the summer months at the SRS, minimum nightly temperatures remain quite high, ensuring copious insect abundance. Standardization of our sampling protocol and high minimum nightly temperatures should have helped ensure that the presence-absence metrics we observed were reflective of actual habitat conditions and structure rather than night-to-night variation in weather. Although the site-to-site variation was high, we believe the subtropical/warm-temperate setting is conducive to both abundance of arthropod prey and presence of bats. Therefore, we believe our relatively large sample size of survey points sampled allowed us to overcome biases associated with those aspects of temporal variation.

Finally, our results are further tempered by the inability to discriminate between red bats and Seminole bats acoustically, our inability to survey Rafinesque's big-eared bat due to its low-amplitude echolocation characteristics, and our failure to record Brazilian free-tailed bats at the SRS. Research on red and Seminole bats at the SRS has indicated that although both species are habitat generalists that forage in both cluttered and open habitats and can day-roost in a variety of forest types and conditions (Carter et al. 2004), red bats tend to roost and forage more commonly in hardwoods, whereas Seminole bats tend to roost and forage more commonly in pines (Carter 1998, Menzel et al. 2000). Had we been able to discriminate between the species, we suspect that a larger landscape-level association with pine or hardwood and upland or bottomland forest conditions would have been demonstrable for these bats. Conversely, virtually nothing is known about the ecology of the Brazilian free-tailed bats at the SRS or in much of the SPR (Menzel et al. 2003). Fortunately, the Rafinesque's big-eared bat has been the subject of previous and ongoing research using radiotelemetry to assess day roosts and foraging habitat on

\section{Literature Cited}

Aldridge, H. D. J. N., and I. L. Rautenbach. 1987. Morphology, echolocation, and resource partitioning in insectivorous bats. Journal of Animal Ecology 56:763-778.

Alig, R. J., and J. Butler. 2004. Area changes for forest cover types in the United States, 1952-1997, with projections to 2050. U.S. Forest Service General Technical Report PNW-GTR-613. U.S. Forest Service Pacific Northwest Research Station, Portland, Oregon, USA. Avila-Flores, R., and M. B. Fenton. 2005. Use of spatial features by or adjacent to the SRS (Clark et al. 1998, Menzel et al. $2001 b$, 2003, S. Loeb, United States Department of Agriculture [USDA] Forest Service, personal communication).

\section{Management Implications}

Despite mediocre performance of our models, our analysis confirms the importance of riparian and wetland areas as foraging habitats for most species of bats in the SPR. Except for the southeastern myotis, most bats in the SPR are considered either habitat generalists or species morphologically adapted to foraging in open, uncluttered environments. Therefore, we believe efforts to manage pine forests for savanna conditions will benefit the bat community in the region. Bat conservation could be a small, albeit important consideration in efforts to rehabilitate and restore longleaf pine communities throughout the SPR on both public and private forestlands (Landers et al. 1995). Along with everincreasing information on the selection of day-roost habitats in the SPR, managers should be able to create, enhance, and maintain good foraging and day-roost habitat, at least in general terms, for the region's bats. Admittedly, there is a need for additional survey work to perform validation of our models or to explore new relationships such as how bat dayroosting and foraging ecology might vary seasonally. However, we believe the SRS might serve as a good baseline for understanding both bat day-roosting ecology (Menzel et al. 2000, 2001a) and foraging ecology (Menzel et al. 2005b) in the SPR. These data should be useful for formulating bat habitat management guidelines in the SPR-a task that is somewhat urgent as this landscape continues to experience urbanization and cumulative wildlife habitat loss.

\section{Acknowledgments}

We thank B. Sparks, D. Linden, J. Johnson, and L. Butler for field and lab assistance. Funding and support for our study was provided by the United States Department of EnergySavannah River Operations Office through the USDA Forest Service-Savannah River and the USDA Forest Service Southern Research Station under Interagency Agreement DE-AI-00SR22188. Additional support was provided by West Virginia University's Swiger Fellowship, the West Virginia University Division of Forestry, the USDA Forest Service Northeastern Research Station, and the National Council of the Paper Industry for Air and Stream Improvement.

foraging insectivorous bats in a large urban landscape. Journal of Mammalogy 86:1193-1204.

Barclay, R. M. R. 1985. Long- verses short-range foraging strategies of hoary (Lasiurus cinereus) and silver-haired (Lasionycteris noctivagans) bats and the consequences for prey selection. Canadian Journal of Zoology 63:2507-2515.

Barton, C. D., J. I. Blake, and D. W. Imm. 2005. Ecological restoration. Pages 84-102 in J. C. Kilgo and J. I. Blake, editors. Ecology and 
management of a forest landscape: fifty years on the Savannah River site. Island, Washington, D.C., USA.

Best, T. L., and M. K. Hudson. 1996. Movements of gray bats (Myotis grisescens) between roost sites and foraging areas. Journal of the Alabama Academy of Science 67:6-14.

Brigham, R. M., S. D. Grindal, M. C. Firman, and J. L. Morissette. 1997. The influence of structural clutter on activity patterns of insectivorous bats. Canadian Journal of Zoology 75:131-136.

Britzke, E. R., and K. L. Murray. 2000. A quantitative method for selection of identifiable search-phase calis using the Anabat system. Bat Research News 41:33-36.

Broders, H. G. 2003. Another quantitative measure of bat species activity and sampling intensity considerations for the design of ultrasonic monitoring studies. Acta Chiropterologica 5:235-241.

Broders, H. G., G. M. Quinn, and G. J. Forbes. 2003. Species status, and the spatial and temporal patterns of activity of bats in southwest Nova Scotia, Canada. Northeastern Naturalist 10:235-241.

Burnham, R. B., and D. R. Anderson. 1998. Model selection and inference: a practical information-theoretic approach. SpringerVerlag, New York, New York, USA.

Carter, T. C. 1998. The foraging ecology of three species of bats at the Savannah River Site, South Carolina. Thesis, University of Georgia, Athens, USA

Carter, T. C., M. A. Menzel, B. R. Chapman, and K. V. Miller. 2004. Partitioning of food resources by syntopic eastern red (Lasiurus borealis), Seminole (L. seminolus) and evening (Nycticeius humeralis) bats. American Midland Naturalist 151:186-191.

Clark, M. K., A. Black, and M. Kiser. 1998. Roosting and foraging activities of Corynorhinus rafinesquii and Myotis austroriparius in the Francis Beidler Forest in South Carolina. Bat Research News 39:162163.

Clem, P. D. 1993. Foraging patterns and the use of temporary roosts in female evening bats, Nycticeius humeralis, at an Indiana maternity colony. Proceedings of the Indiana Academy of Science 102:201206.

Cook, J. G., T. W. Stutzman, C. W. Bowers, K. A. Brenner, and L. L. Irwin. 1995. Spherical densiometers produce biased estimates of forest canopy cover. Wildlife Society Bulletin 23:711-717.

Crampton, L. H., and R. M. R. Barclay. 1997. Selection of roosting and foraging habitat by bats in different-aged aspen mixedwood stands. Conservation Biology 12:1347-1358.

Elmore, L. W., D. A. Miller, and F. J. Vilella. 2005. Foraging area size and habitat use by red bats (Lasiurus borealis) in an intensively managed pine landscape in Mississippi. American Midland Naturalist 153:405-417.

Erickson, J. L., and S. D. West. 2003. Associations of bats with local structure and landscape features in western Oregon and Washington. Biological Conservation 109:95-102.

Evelyn, M. J., D. A. Stiles, and R. A. Young. 2004. Conservation of bats in suburban landscapes: roost selection by Myotis yumanensis in a residential area in California. Biological Conservation 115:463-473.

Ford, W. M., M. A. Menzel, J. L. Rodrigue, J. M. Menzel, and J. B. Johnson. 2005. Relating bat species presence to simple habitat measures in a central Appalachian forest. Biological Conservation 126:528-539.

Francl, K. E., W. M. Ford, and S. B. Castleberry. 2004. Bat activity in central Appalachian wetlands. Georgia Journal of Science 62:87-94.

Gehrt, S. D., and J. E. Chelsvig. 2003. Bat activity in an urban landscape: patterns at the landscape and microhabitat scale. Ecological Applications 13:939-950.

Gehrt, S. D., and J. E. Chelsvig. 2004. Species-specific patterns of bat activity in an urban landscape. Ecological Applications 14:625-635.

Grindal, S. D., and R. M. Brigham. 1998. Short-term effect of smallscale habitat disturbance on activity by insectivorous bats. Journal of Wildlife Management 62:996-1003.

Grindal, S. D., J. L. Morisette, and R. M. Brigham. 1999. Concentration of bat activity in riparian habitats over an elevational gradient. Canadian Journal of Zoology 77:972-977.

Guthery, F. S., L. A. Brennan, M. J. Peterson, and J. J. Lusk. 2005 Information theory in wildlife science: critique and viewpoint. Journal of Wildlife Management 69:457-465.

Hanula, J. L., K. E. Franzreb, and W. D. Pepper. 2000. Longleaf pine characteristics associated with arthropods available for redcockaded woodpeckers. Journal of Wildlife Management 62:9961003.

Hart, J. A., G. L. Kirkland, and S. C. Grossman. 1993. Relative abundance and habitat use by tree bats, Lasiurus spp., in southcentral Pennsylvania. The Canadian Field-Naturalist 107:208-212.

Hayes, J. P. 1997. Temporal variation in activity of bats and the design of echolocation-monitoring studies. Journal of Mammalogy 78:514524.

Hayes, J. P. 2000. Assumptions and practical considerations in the design and interpretation of echolocation-monitoring studies. Acta Chiropterologica 2:225-236.

Hollifield, B. K., and R. W. Dimmick. 1995. Arthropod abundance relative to forest management practices benefiting ruffed grouse in the southern Appalachians. Wildlife Society Bulletin 23:756-764.

Hosmer, D. W., and S. Lemeshow. 2000. Applied logistic regression. Wiley-Interscience, New York, New York, USA.

Hutchinson, J. T., and M. J. Lacki. 1999. Foraging behavior and habitat use of red bats in mixed mesophytic forests of the Cumberland Plateau, Kentucky. Pages 171-177 in J. W. Stringer and D. L. Loftis, editors. Proceedings, 12th Central Hardwood Forest Conference, 28 February-2 March 1999, Lexington, Kentucky, USA. U.S. Forest Service General Technical Report SRS-24, U.S. Forest Service, Southern Research Station, Asheville, North Carolina, USA.

Imm, D. W., and K. W. McLeod. 2005. Plant communities. Pages 106161 in J. C. Kilgo and J. I. Blake, editors Ecology and management of a forested landscape: 50 years of natural resource stewardship on the Savannah River Site. Island, Washington D.C., USA.

Johnson, J. B. 2003. Spatial and predictive foraging models for grays bats in northwest Georgia and a comparison of two acoustical bat survey techniques. Thesis, West Virginia University, Morgantown, USA.

Johnson, J. B., M. A. Menzel, J. W. Edwards, and W. M. Ford. 2002. A comparison of two acoustical bat survey techniques. Wildlife Society Bulletin 30:931-936.

Jung, T. S., I. D. Thompson, R. D. Titman, and A. P. Applejohn. 1999. Habitat selection by forest bats in relation to mixed-wood stand types and structure in central Ontario. Journal of Wildlife Management 63: 1306-1319.

Kalcounis, M. C., and R. M. Brigham. 1995. Intraspecific variation in wing-loading affects habitat use by little brown bats (Myotis lucifugus). Canadian Journal of Zoology 73:89-95.

Kirkman, L. K., R. F. Lide, G. Wein, and R. R. Sharitz. 1996. Vegetation changes and land-use legacies of depression wetlands of the western coastal plain of South Carolina: 1951-1992. Wetlands 16: 564-576.

Krishon, D. M., M. A. Menzel, T. C. Carter, and J. Laerm. 1997. Notes on the home range of four species of Vespertilionid bats (Chiroptera) on Sapelo Island, Georgia. Georgia Journal of Science 55:215-223.

Landers, J. L., D. H. Van Lear, and W. D. Boyer. 1995. The longleaf pine forests of the Southeast: requiem or renaissance? Journal of Forestry 93:39-44

Loeb, S. C., and J. M. O'Keefe. In press. Habitat use by forest bats in South Carolina in relation to local, stand, and landscape characteristics. Journal of Wildlife Management 70:1210-1218.

Lumsden, L. F., and A. F. Bennett. 2005. Scattered trees in rural landscapes: foraging habitat for insectivorous bats in south-eastern Australia. Biological Conservation 122:205-222.

Menzel, J. M., M. A. Menzel, J. C. Kilgo, W. M. Ford, and J. W. Edwards. 2005a. Bat response to Carolina bays and wetland restoration in the southeastern U.S. Coastal Plain. Wetlands 25: 542-550.

Menzel, J. M., M. A. Menzel, J.C. Kilgo, W. M. Ford, J. W. Edwards, and G. F. McCracken. 2005b. Effect of habitat and foraging height on bat activity in the Coastal Plain of South Carolina. Journal of Wildlife Management 69:235-245.

Menzel, M. A. 1998. The effects of group selection timber harvest in a southeastern bottomland hardwood community on the roosting and foraging behavior of tree-roosting bats. Thesis, University of Georgia, Athens, USA.

Menzel, M. A., T. C. Carter, B. R. Chapman, and J. Laerm. 1998. Quantitative comparison of tree roosts used by red bats (Lasiurus 
borealis) and Seminole bats (L. seminolus). Canadian Journal of Zoology 76:630-634.

Menzel, M. A., T. C. Carter, W. M. Ford, and B. R. Chapman. $2001 a$. Tree-roost characteristics of subadult and female adult evening bats (Nycticeius humeralis) in the Upper Coastal Plain of South Carolina. American Midland Naturalist 145:112-119.

Menzel, M. A., T. C. Carter, W. M. Ford, B. R. Chapman, and J. Ozier. 2000. Summer roost tree selection by eastern red bats (Lasiurus borealis), Seminole bats ( $L$. seminolus) and evening bats (Nycticeius humeralis) in the upper Coastal Plain of South Carolina. Proceedings of the Annual Conference of the Southeastern Association of Fish and Wildlife Agencies 54:304-313.

Menzel, M. A., T. C. Carter, J. M. Menzel, W. M. Ford, and B. R. Chapman. 2002. Effects of group selection silviculture in bottomland hardwoods on the spatial activity patterns of bats. Forest Ecology and Management 162:209-218.

Menzel, M. A., J. M. Menzel, W. M. Ford, J. W. Edwards, T. C. Carter, J. B. Churchill, and J. C. Kilgo. 2001b. Notes on the homerange, habitat use, and diet of reproductively active male Rafinesque's bigeared bats, Corynorhinus rafinesquii (Chiroptera: Vespertilionidae), in the upper Coastal Plain of South Carolina. American Midland Naturalist 145:402-408.

Menzel, M. A., J. M. Menzel, J. C. Kilgo, W. M. Ford, T. C. Carter, and J. W. Edwards. 2003. Bats of the Savannah River Site and vicinity. U.S. Forest Service General Technical Report SRS-GTR-68. U.S. Forest Service, Southern Research Station, Asheville, North Carolina, USA.

Miller, B. W. 2001. A method for determining relative activity of free flying bats using a new activity index for acoustic monitoring. Acta Chiropterologica 3:93-105.

Murray, S. W., and A. Kurta. 2004. Nocturnal activity of the endangered Indiana bat (Myotis sodalis). Journal of Zoology 262:197-206.

Nielsen, S. E., C. J. Johnson, D. C. Heard, and M. C. Boyce. 2005. Can models of presence-absence be used to scale abundance? Two case studies considering extremes in life history. Ecography 28:197208.

Odom, R. H., W. M. Ford, J. W. Edwards, C. Stihler, and J. M. Menzel. 2001. Modeling Virginia northern flying squirrel habitat in the central Appalachians. Biological Conservation 99:245-252.

Owen, S. F., M. A. Menzel, J. W. Edwards, W. M. Ford, J. M. Menzel, B. R. Chapman, P. B. Wood, and K. V. Miller. 2004. Bat activity in harvested and intact forest stands in the Allegheny Mountains. Northern Journal of Applied Forestry 21:154-159.

Royle, J. A., J. D. Nichols, and M. Kery. 2005. Modeling occurrence and abundance of species when detection is imperfect. Oikos 110: 353-359.

Russ, J. M., and W. I. Montgomery. 2002. Habitat associations of bats in Northern Ireland: implications for conservation. Biological Conservation 108:49-58.

Russell, K. R., T. J. Mabee, and M. B. Cole. 2004. Distribution and habitat of Columbia torrent salamanders at multiple spatial scales in managed forests of northwestern Oregon. Journal of Wildlife Management 68:403-415.
SAS Institute. 1990. User's guide: statistics. Fifth edition. SAS Institute, Cary, North Carolina, USA.

SAS Institute. 1995. Logistic regression examples using the SAS system. SAS Institute, Cary, North Carolina, USA.

Seidman, V. M., and C. J. Zabel. 2001. Bat activity along intermittent streams in northwestern California. Journal of Mammalogy 82:738747.

Steel, R. G. D., and J. H. Torrie. 1980. Principles and procedures of statistics: a biometrical approach. McGraw-Hill Company, New York, New York, USA.

Tibbels, A. E., and A. Kurta. 2003. Bat activity is low in thinned and unthinned stands of red pine. Canadian Journal of Forest Research 33:2436-2442.

USDA Forest Service. 2005. Natural Resource Information System. Available at $<$ http://www.fs.fed.us/emc/nris/products/fsveg/ $>$. Accessed 2006 Jan 11.

Vaughan, N., G. Jones, and S. Harris. 1997. Habitat use by bats (Chiroptera) assessed by means of a broad-band acoustic method. Journal of Applied Ecology 34:716-730.

Verboom, B., and H. Huitema. 1997. The importance of linear landscape elements for the pipistrelle Pipistrellus pipistrellus and the serotine bat Eptesicus serotinus. Landscape Ecology 12:117125.

Wagner, D. M., and L. C. Drickamer. 2004. Abiotic habitat correlates of Gunnison's prairie dogs in Arizona. Journal of Wildlife Management 68:188-197.

Warren, R. D., D. A. Waters, J. D. Altringham, and D. J. Bullock. 2000. The distribution of Dauberton's bat (Myotis daubentonii) and pipistrelle bats (Pipistrellus pipistrellus) (Nespertilionidae) in relation to small-scale variation in riverine habitat. Biological Conservation 92: 85-91.

Wear, D. N., and J. G. Greis. 2002. Southern forest resource assessment. U.S. Forest Service General Technical Report SRS-54. U.S. Forest Service, Southern Research Station. Asheville, North Carolina, USA.

White, D. L. 2005. Land-use history. Pages 1-12 in J. C. Kilgo and J. I. Blake, editors. Ecology and management of a forested landscape: 50 years of natural resource stewardship on the Savannah River Site. Island, Washington, D.C., USA.

Wickramasinghe, L. P., S. Harris, G. Jones, and N. Vaughan. 2003. Bat activity and species richness on organic and conventional farms: impact of agricultural intensification. Journal of Applied Ecology 40: 984-993.

Workman, S. W., and K. W. McLeod. 1990. Vegetation of the Savannah River Site: major community types. National Environmental Research Park Program Publication SRO-NERP-19. Savannah River Ecology Laboratory, Aiken, South Carolina, USA.

Zaniewski, A. E., A. Lehman, and J. Overton. 2002. Predicting species spatial distributions using presence-only data: a case study of native New Zealand ferns. Ecological Modeling 157:261-280.

Associate Editors: Brooks and Ford. 